\title{
Accidental diagnosis and conservative management of a case of first- trimester caesarean scar ectopic pregnancy
}

\author{
Ahmed M. Abbas*, Shymaa S. Ali, Mohammed Nagy, Fady Nasif
}

Department of Obstetrics and Gynecology, Faculty of Medicine, Assiut University, Egypt

Received: 27 January 2018

Accepted: 28 February 2018

\section{*Correspondence:}

Dr. Ahmed M. Abbas,

E-mail: bmr90@ @otmail.com

Copyright: () the author(s), publisher and licensee Medip Academy. This is an open-access article distributed under the terms of the Creative Commons Attribution Non-Commercial License, which permits unrestricted non-commercial use, distribution, and reproduction in any medium, provided the original work is properly cited.

\begin{abstract}
Cases of Caesarean Scar Ectopic Pregnancy (CSEP) are becoming increasingly common at tertiary care hospitals because of increase in rate of CS. It may lead to horrible consequences, such as uncontrolled bleeding and uterine rupture (UR), which might require hysterectomy and result in subsequent loss of fertility. This report covers a case of a CSEP discovered early at 9 weeks of gestation in a 25 -year-old woman coming for antenatal care. Conservative management of the uterus was performed with removal of the sac and repair of the uterine scar. The patient's postoperative period was uneventful, and she was discharged 3 days after surgery. CSEP should be detected early to prevent its catastrophic sequences. Although it is a rare complication of cesarean section, CSEP must be kept in the minds of obstetricians facing emergency cases.
\end{abstract}

Keywords: Cesarean section, Ectopic pregnancy, First-trimester, Maternal morbidity

\section{INTRODUCTION}

Ectopic pregnancy is the most important cause of pregnancy-related first-trimester death in the United States, occurring in approximately $2 \%$ of pregnancies. ${ }^{1}$ Cesarean scar ectopic pregnancy (CSEP) is diagnosed as ectopic pregnancy implanted in the myometrium at the site of a previous cesarean section scar. ${ }^{2}$ The exact incidence of CSEP has not been determined because limited number of cases have been reported in the literature. However, the incidence of such cases seems to be on the rise. ${ }^{3}$

Although it is uncommon, this iatrogenic condition can be life-threatening because of the very high risk of complications such as uterine rupture and massive hemorrhage. ${ }^{4}$ Ultrasound is the primary diagnostic modality. With increased index of doubt and wide use of transvaginal sonography, more cases of CSEP are being diagnosed in early pregnancy, thus allowing early and rapid interventions and conservation of uterus and fertility.

Any delay in either diagnosis or intervention may lead to uterine rupture, hysterectomy, and significant maternal morbidity and mortality. ${ }^{5}$

This report presents a case of a CSEP accidentally diagnosed early at 9 weeks at the first antenatal visit that allows conservative management of the condition without subsequent morbidity.

\section{CASE REPORT}

In August 2017 a 25-year-old woman gravida 3 para2+0 with 2 living females presented to the outpatient Anetnatal Care Clinic of Women's Health Hospital in Assiut, Egypt, for routine antenatal checkup after 2 months of amenorrhea and positive urine pregnancy test. She was otherwise asymptomatic. She had a history of 2 
previous caesarean sections (CS); the first one was 4 years ago and the second one was 2 years ago.

A pelvic ultrasound was obtained revealing an endometrial cavity without evidence of an intrauterine gestational sac.

However, a gestational sac with embryo CRL $=8$ weeks had a positive cardiac pulsation was evident within a defect in the anterior myometrium in the lower uterine segment, corresponding to the site of her prior CS (Figure $1)$.

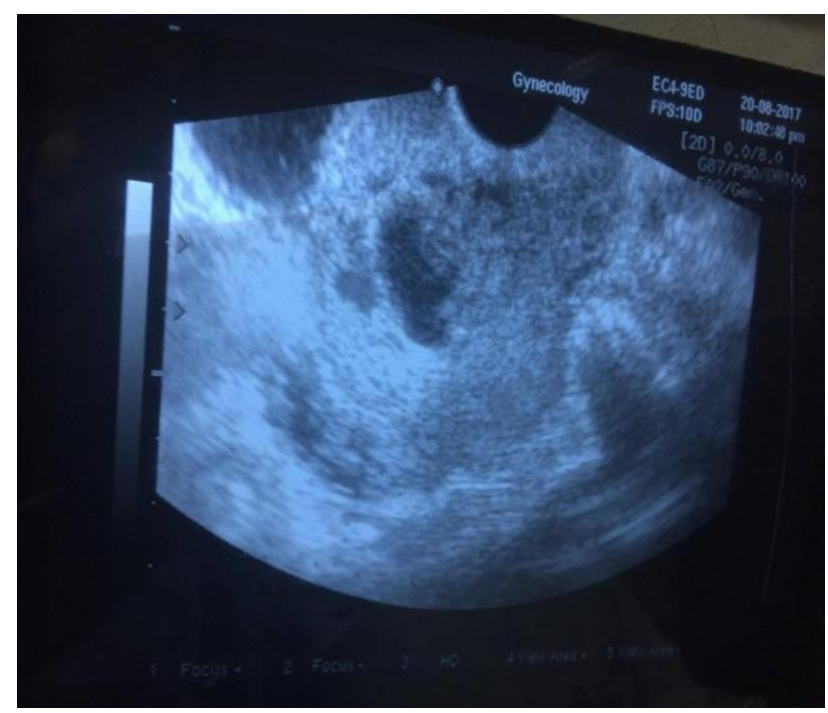

Figure 1: Ultrasound picture of a gestational sac at the site of the lower uterine segment.

The myometrial thickness surrounding was less than $10 \mathrm{~mm}$. There was no evidence of free pelvic fluid. These findings were interpreted to represent a CSEP. The patient was prepared for termination of pregnancy by laparotomy; her hemoglobin level was $11.5 \mathrm{~g} / \mathrm{dL}$.

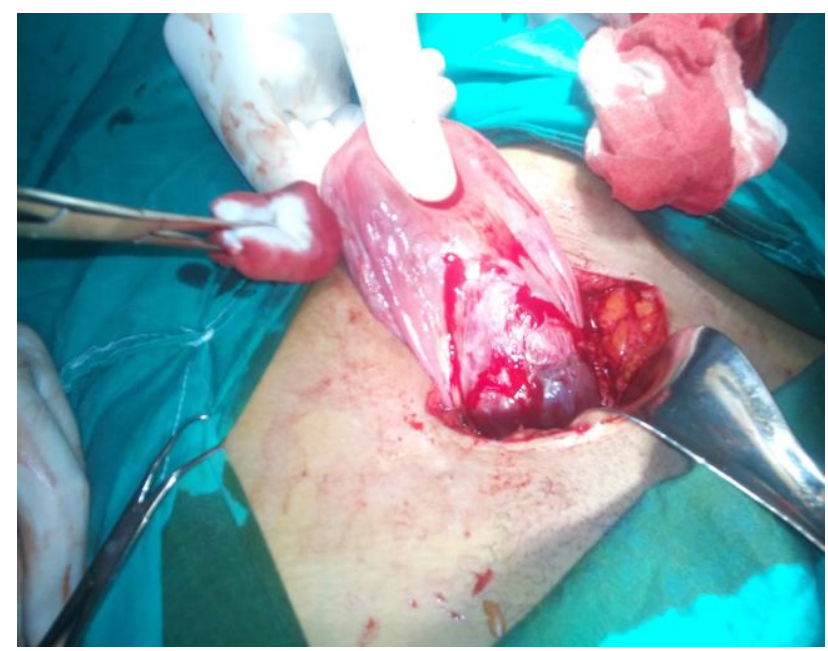

Figure 2: The site of cesarean scar intraoperative shows intact bulging gestational sac.
Laparotomy was carried out through a Pfannensteil incision under spinal anesthesia after counseling the patient about her current condition and obtaining informed consent. The previous uterine scar was intact but bulging out ward by the implanted gestational sac (Figure 2).

New surgical technique was used to preserve the uterus and minimize the blood loss in the form of: bilateral uterine artery ligation, then elliptical segment including the previous uterine scar, gestational sac and placenta was removed. Then the uterine incision was sutured in two layers using vicryl number 1 . Both adnexa were free. No intra-operative blood transfusion. The patient had an excellent postoperative course and was discharged at the third day post-operative.

\section{DISCUSSION}

Implantation of a gestational sac within a cesarean scar is the rarest form of ectopic pregnancy, currently represents less than $1 \%$ of all pregnancies; however, the rate is definitely increasing due to rising rate of LSCS. ${ }^{6}$

There are several theories which clarify the occurrence of intramural ectopic pregnancy. The most accepted theory seems to be that the blastocyst invades into the myometrium through a microscopic dehiscent tract, which may be the result of trauma of a previous caesarean section or any other uterine surgery. ${ }^{7}$ Another mechanism for intramural implantation of the gestational sac may be in vitro fertilization and embryo transfer, even in the absence of previous uterine trauma or surgery. ${ }^{8}$

There are two types of CSEPs. The first type has deep implantation in a CS defect up to the serosal lining into the bladder and the abdominal cavity. In the second type there is progression away from the serosal lining growing inside the uterine cavity. ${ }^{7}$

The first type is more catastrophic with high incidence of uterine rupture. Abbas et al reported a case of first type CSEP in which the sac grows deeply within the myometrium towards the uterine cavity UR occurred at the tenth week of gestation and the patient did not know that she was pregnant until the occurrence of the UR. ${ }^{9}$

Ultrasonography is the first-line diagnostic tool for approaching CSEP and confirmed by MRI or during laparoscopy and/or laparotomy. ${ }^{10}$ Early diagnosis is very important, as it can prevent such serious complications as UR with a high risk of hysterectomy. ${ }^{11}$

Because this is a rare condition, there is no uniform approach to the treatment. Previous reports in the literature included a variety of medical and surgical strategies such as the use of systemic methotrexate, surgical sac aspiration, hysteroscopic evacuation, laparoscopic removal, open surgical treatment, and hysterectomy. ${ }^{12}$ Most authors reported that expectant 
management is not suitable given the significant risk of uterine rupture. ${ }^{13}$ Dilation and curettage are inadequate because the trophoblastic tissue is actually located outside the uterine cavity and unreachable. Such attempts can cause perforation of the implantation site could occur and result in severe peritoneal hemorrhage. ${ }^{4}$

In the current case, the patient was hemodynamically stable, but the CSEP was invading the myometrium. Therefore, laparotomy was done for fear of UR. To decrease the bleeding firstly bilateral uterine artery ligation was done then elliptical uterine segment including the previous uterine scar, gestational sac and the trophoblastic tissues was removed. By this technique the patient fertility was preserved.

\section{CONCLUSION}

In conclusion, Ectopic pregnancy in a site of a CS scar should be detected early to prevent CSEP's catastrophic sequelae. CSEP must be kept in mind of obstetricians facing emergency cases.

Funding: No funding sources

Conflict of interest: None declared

Ethical approval: The study was approved by the Institutional Ethics Committee

\section{REFERENCES}

1. Chang J, Elam-Evans LD, Berg CJ, Herndon J, Flowers L, Seed KA, et al., Pregnancy related mortality surveillance-United States, 1991-1999. MMWR Surveill Summ. 2003;52:1-9.

2. Herman A, Weinraub Z, Avrech O, Maymon R, RonEl R, Bukovsky Y. Follow up and outcome of isthmic pregnancy located in a previous caesarean section scar. BJOG: Int $\mathbf{J}$ Obstet Gynaecol. 1995;102(10):839-41.

3. Ghezzi F, Lagana D, Franchi M, Fugazzola C, Bolis P. Conservative treatment by chemotherapy and uterine arteries embolization of a Caesarian scar pregnancy. Eur J Obstet Gynecol Reprod Biol. 2002;103:88-91.
4. Maymon R, Halperin R, Mendlovic S, Schneider O, Herman A. Ectopic pregnancies in a Cesarean scar: review of the medical approach to an iatrogenic complication. Hum Reprod. 2004;19:278-84.

5. Peng KW, Lei Z, Xiao TH, Jia FG, Zhong WX, Gao $\mathrm{Y}$ et al., First trimester caesarean scar ectopic pregnancy evaluation using MRI. Clin Radiol. 2014;69:123-9.

6. Seow KM, Huang LW, Lin YH, Lin MY, Tsai YL, Hwang JL. Caesarean scar pregnancy: issues in management. Ultrasound Obstet Gynecol. 2004;23:247-53.

7. Cheng PJ, Chueh HY, Soong YK. Sonographic diagnosis of a uterine defect in a pregnancy at 6 weeks gestation with a history of curettage. Ultrasound Obstet Gynecol. 2003;21(5):501-3.

8. Hamilton CJ, Legarth J, Jaroudi KA. Intramural pregnancy after in vitro fertilization and embryo transfer. Fertil Steril. 1992;57:215-7.

9. Abbas AM, Ali SS, Michael A, Badran SA. Caesarean Scar Ectopic Pregnancy Complicated by Uterine Rupture at 10 Weeks Gestation. J Gynecol Surg. 2017;33(6):261-3.

10. Yu XL, Zhang N, Zuo WL. Cesarean scar pregnancy: an analysis of 100 cases. Z Honghua Med J. 2011;91(45):3186-9.

11. Ben Nagi J, Helmy S, Ofili-Yebovi D, Yazbek J, Sawyer E, Jurkovic D. Reproductive outcomes of women with a previous history of Caesarean scar ectopic pregnancies. Hum Reprod. 2007, 22: 2012-5.

12. Ash A, Smith A, Maxwell D. Caesarean scar pregnancy. BJOG: Int J Obstet Gynaecol. 2007;114(3):253-63.

13. Rotas MA, Haberman S, Levgur M. Cesarean scar ectopic pregnancies etiology, diagnosis and management. Obstet Gynecol. 2006;107(6):1373-81.

Cite this article as: Abbas AM, Ali SS, Nagy M, Nasif F. Accidental diagnosis and conservative management of a case of first-trimester caesarean scar ectopic pregnancy. Int J Reprod Contracept Obstet Gynecol 2018;7:1628-30. 